\title{
Choosing the appropriate project management structure, project financing, land acquisition and contractual process for Indian railway mega-projects: a case study of the Dedicated Freight Corridor project
}

Bodhibrata Nag, Indian Institute of Management Calcutta, India Jeetendra Singh and Ved Mani Tiwari, Ministry of Railways, India

\begin{abstract}
A large number of railway mega-projects are planned or are under implementation for capacity augmentation, for serving the needs of trade, specific regions or industry sectors. Since transport capacity is one of the main levers of economic progress, it is essential that augmentation of transport capacity is not held up. It is therefore essential to choose the appropriate project management structure, project financing, land acquisition and contractual process to ensure design, construction and commissioning of projects without cost and time overruns. These choices have to be made keeping in view the context of the organisational technical capacity, financial capability, contractor capacity, and industry and trade growth pattern. This paper examines the various project management structures, methods of project financing, land acquisition and contractual processes along with their advantages and disadvantages. The paper takes the specific case of the Dedicated Freight Corridor project to examine the appropriateness of options.
\end{abstract}

Key words: railway; organisation; contracts; financing; land acquisition; India

\section{Introduction}

The Dedicated Freight Corridor (DFC) project of the Indian Railways (IR) has been conceived to create capacity and relieve congestion on the 'golden quadrilateral' or the high density network connecting the four metros, Mumbai, Delhi, Kolkata and Chennai. (Secretariat for the Committee on Infrastructure, Planning Commission 2005). Table 1 shows the network expansion of IR from 1950 to 2010.

Table 1: Network expansion of Indian Railways 1950-2010

\begin{tabular}{|l|l|l|l|}
\hline Year & Track-km (thousand) & $\begin{array}{l}\text { Freight traffic } \\
\text { (billion ton-km) }\end{array}$ & $\begin{array}{l}\text { Passenger traffic (billion } \\
\text { passenger-km) }\end{array}$ \\
\hline $1950-51$ & 59 & 38 & 67 \\
\hline $2010-11$ & 114 & 636 & 978 \\
\hline
\end{tabular}

Source: Saxena 1991; Indian Railways 2012

The golden quadrilateral, though constituting only $16 \%$ of the network, carries more than 55\% of the freight traffic. (Dedicated Freight Corridor Corporation of India Ltd 2012). It also carries a major part of IR's passenger traffic, resulting in low average speeds of freight trains. Since freight and passenger trains on IR share the same tracks, the speed differential between the two further impacts the capacity. The DFC would enable segregation of freight and passenger traffic (Ministry of Railways (Railway Board) 2009). 
The increase in the IR's network capacity through doubling, gauge conversion, electrification, traffic facility improvement works, etc has not kept pace with the freight transportation demands of the Indian economy, which has been on a high growth path (Table 2). Freight traffic has therefore gradually shifted to road. Modal share of railways in freight transport has decreased from $50 \%$ in the $1960 \mathrm{~s}$ to $36 \%$ in 2007-08 (RITES Ltd 2008), in contrast to about 46\% in China and the United States (McKinsey and Company 2010). A situation has arisen wherein road and rail infrastructure deficiencies have become one of the major deterrents of India's competitive position in terms of manufacturing and trade. India today ranks 56th in the world Logistics Performance Index infrastructure rankings (World Bank 2012).

Table 2: Growth of Indian Economy 1950-2010

\begin{tabular}{|l|l|l|l|l|l|}
\hline Year & $\begin{array}{l}\text { GDP at current } \\
\text { prices (Rs. } \\
\text { billion) }\end{array}$ & $\begin{array}{l}\text { Coal production } \\
\text { (million tonnes) }\end{array}$ & $\begin{array}{l}\text { Steel production } \\
\text { (million tonnes) }\end{array}$ & $\begin{array}{l}\text { Cement } \\
\text { production } \\
\text { (million tonnes) }\end{array}$ & $\begin{array}{l}\text { Foodgrains } \\
\text { (million tonnes) }\end{array}$ \\
\hline $1950-51$ & 97 & 32 & 1 & 3 & 51 \\
\hline $2010-11$ & 71,574 & 571 & 76 & 216 & 242 \\
\hline
\end{tabular}

It is desirable to increase rail share in national freight transportation from the economic and logistic costs perspectives, since rail transport is more energy efficient, environmentally and socially sustainable and less resource intensive compared with road. Increased investment is thus required in railway infrastructure to create capacity and thereby increase the rail share in freight traffic. In view of the above, the Dedicated Freight Corridor Corporation of India Ltd (DFCCIL) was formed as a wholly owned company of IR:

\footnotetext{
to build a corridor with appropriate technology that enables Indian railways to regain its market share of freight transport by creating additional capacity and guaranteeing efficient, reliable, safe and cheaper options for mobility to its customers (Dedicated Freight Corridor Corporation of India Ltd 2012).
}

The DFCCIL has been charged with the responsibility of construction and operation of the Western and Eastern DFCs, details of which are given in Table 3. The DFCs have been designed as heavy haul corridors. Heavier, longer and faster freight trains will operate on the DFCs, with lower unit costs of operations and maintenance, rolling stock, manpower and energy. Bulk trains (6000/12000 ton) and double-stack container trains (4500 ton) at 25 ton axle load will run on Eastern and Western DFCs, respectively. Infrastructure has been designed such that it can be upgraded to 32.5 ton axle load in the future. The track, bridge, electrification and signalling infrastructure are being designed and constructed to operate the DFCs as heavy haul networks with maximum speeds of $100 \mathrm{kmph}$ and average speeds of $65 \mathrm{kmph}$.

Modern high horsepower locomotives and high capacity wagons are also being concurrently developed for moving traffic on the corridors. In order to enable seamless movement of traffic between the DFC network and the existing IR network, feeder routes on the existing IR network are also been upgraded; the feeder route lengths for the Western and Eastern DFCs are given in Table 3. The Western DFC will complement the Delhi-Mumbai Industrial Corridor (DMIC) initiative, which is a Japanese-Indian collaborative project for comprehensive infrastructure development to create India's largest industrial belt zone by linking the industrial parks and 
harbours of the six states between Delhi and Mumbai to promote foreign export and direct investment. Under the DMIC initiative, industrial parks and logistics bases will be created in the area $150 \mathrm{~km}$ to either side of the Western DFC. The DFCs are conceived as corridors complementing the IR network. DFCCIL will create and maintain infrastructure, which would be utilised by IR to operate its trains. IR feeder routes will bring traffic from originating terminals and transferred to DFCs at junctions for destination terminals, and vice versa.

Table 3. Salient features of DFCs ${ }^{1}$

\begin{tabular}{|l|l|l|}
\hline Feature & Western DFC & Eastern DFC \\
\hline Route length $(\mathrm{km})$ & 1534 & 1839 \\
\hline Route & JNPT-Dadri & Dankuni-Ludhiana \\
\hline Feeder Route length $(\mathrm{km})$ & 1516 & 3071 \\
\hline $\begin{array}{l}\text { Projected traffic in million tonnes } \\
(2021)\end{array}$ & 128 & 144 \\
\hline Land Acquisition required & 6587 hectares & 4592 hectares \\
\hline Project cost (Rs.billion) & 406 & 161 \\
\hline Funding Agency & $\begin{array}{l}\text { Japan International Cooperation } \\
\text { Agency }\end{array}$ & World Bank \\
\hline Loan component (\%) & 80 & 67 \\
\hline $\begin{array}{l}\text { Number of Field Project Units } \\
\text { Project Completion Target }\end{array}$ & 7 & 6 \\
\hline
\end{tabular}

Source: Dedicated Freight Corridor Corporation of India Ltd 2012

A large number of similar railway mega-projects are being planned or are under implementation for capacity augmentation or serving needs of trade, specific regions or industry sectors. Since transport capacity is one of the main levers of economic progress, it is essential that augmentation of transport capacity is not held up. It is therefore essential to choose the appropriate project management structure, project financing, land acquisition and contractual processes to ensure design, construction and commissioning of projects without cost and time overruns. These choices have to be made keeping in view the context of the region's socioeconomic conditions, organisational technical capacity, financial capability, contractor capacity and industry and trade growth patterns. This paper examines the various project management structures, methods of project financing, land acquisition and contractual processes along with their impact on time and cost overruns. The paper takes the specific case of the Eastern Dedicated Freight Corridor Project to examine the appropriateness of the options (Figure 1).

\footnotetext{
${ }^{1}$ JNPT is the abbreviation for Jawaharlal Nehru Port Trust, which is also known as Nhava Sheva port and is located on the mainland across the island-city of Mumbai. It is the largest container port of India.
} 


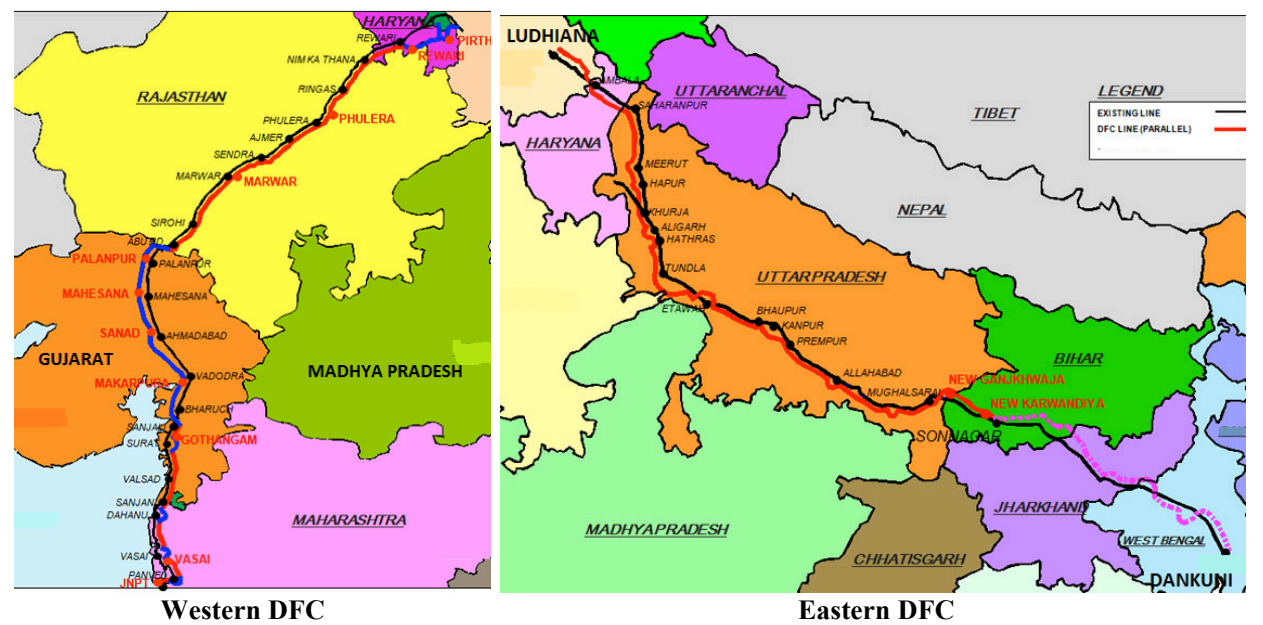

Figure 1: Map of Eastern and Western DFC

Source: Dedicated Freight Corridor Corporation of India Ltd 2012

Project execution in the railway sector is universally acknowledged to be very challenging. The myriad challenges include topographical, geological, hydrological, ecological, climatic and attendant technical challenges, assimilation of diverse components forming complex railway systems, social and environmental impacts and their appropriate mitigation measures, stakeholders' management and legal/regulatory compliance issues. However, IR has been expanding and periodically replacing its assets (eg, replacing wooden with concrete sleepers, upgrading speed potentials of its 133,000 odd bridges, replacement of track with long welded rails, optical fibre communication systems for train communication, doubling of single lines, unifying the gauge, etc) through project management. Table 1 gives an indication of the expansion of the IR network, while Table 4 shows the extent of project activities in IR for gauge conversion, doubling of lines and electrification. Besides this, IR's engineers have been actively involved in building metro systems (eg, $410 \mathrm{~km}$ underground metro system in Delhi) and the challenging mountain railways (eg, 738 km Mumbai-Mangalore Konkan railways and the $345 \mathrm{~km}$ Jammu-UdhampurSrinagar-Baramulla Railway Link, JUSBRL).

Table $4^{2}$

\begin{tabular}{|c|c|c|c|}
\hline Year & $\begin{array}{c}\text { BG as \% of total network } \\
\text { route km }\end{array}$ & $\begin{array}{c}\text { Double line as \% of total } \\
\text { network route km }\end{array}$ & $\begin{array}{c}\text { Electrified line as \%o of } \\
\text { total network route km }\end{array}$ \\
\hline $1950-51$ & 46 & 9 & 0.7 \\
\hline $2010-11$ & 86 & 30 & 30 \\
\hline
\end{tabular}

Source: Indian Railways 2012; Saxena 1991; Ministry of Railways, Government of India 1952

However, as in other Indian infrastructure sectors, IR's projects also suffer from cost and time overruns. The major reasons are the inadequacy of funds allotted for the projects, problems of acquisition of land required for the project and security problems in the project area. Other reasons for time overruns are lack of supporting infrastructure facilities, delay in finalisation of detailed engineering plans, scope

\footnotetext{
${ }^{2} \mathrm{BG}$ is the abbreviation for broad gauge track with gauge of $1676 \mathrm{~mm}$. The other track gauges prevalent on IR are meter gauge (MG, $1000 \mathrm{~mm})$ and narrow gauge $(\mathrm{NG}, 762$ and $610 \mathrm{~mm})$. The gauge conversions from NG and MG to BG were undertaken in early 1990s as Project Unigauge.
} 
changes, delays in scope finalisation, unanticipated geological conditions and lack of familiarity with latest technology. Other reasons for cost overruns are time overruns, changes in foreign exchange rates and statutory duties, increase in cost of rehabilitation of displaced persons and providing environmental safeguards, increase in cost of land acquisition and inflation over project duration. (Ministry of Statistics and Programme Implementation (Infrastructure \& Project Monitoring Division), Government of India 2008).

Doloi et al's (2012) study of delays of Indian construction projects identified the following seven critical factors in descending order of importance:

i) lack of commitment by client, contractor and vendors leading to accidents, improper or obsolete construction methods, delay in material delivery

ii) inefficient site management due to ambiguous specifications, unskilled labour, ineffective supervision, inadequate experience of contractor, lack of control over sub-contractors

iii) poor site coordination due to lack of coordination between site and design office, non-availability of drawings/designs on time, unrealistic time schedule built in the contract

iv) improper planning in ignoring extreme weather conditions which lead to low labour productivity and therefore lead to errors in time estimation; improper planning for recruitment of skilled operators for specialised equipment; improper planning for the requirement of equipment and their utilisation

v) lack of clarity of project scope resulting in rework or scope creep due to misunderstanding by the contractor or project manager

vi) lack of communication with local authorities resulting in delays in permissions; lack of communication between contractor and client results in delay in approval of stages substandard contract, selection of contractor with inadequate experience or skill sets, optimistic cost and time duration built in the contract

We examine the Eastern DFC project to determine the measures taken to mitigate the major reasons for the time and cost overruns listed above.

There is no research available on the measures taken to improve the success rate of public sector or IR projects in India. This paper attempts to fill this gap, since it is worthwhile analysing the evolution of mechanisms for project success in an organisation in existence in a developing country since 1853 . The research is based on an examination of IR's process manuals and annual reports of the DFCCIL, IR, World Bank's project documents of the Eastern DFC along with discussions with senior management personnel. The remainder of the paper is organised as follows: the project structure of DFCCIL; the DFC project financing process; DFC's land acquisition process; project contracting process; the impact of the project structure, financing, land acquisition and contracting processes on mitigating time and cost overruns; and concluding with future research directions.

\section{Project structure}

The IR network is carved into 17 geographical zones for administrative convenience. Each zone is again divided into divisions; IR today has 68 divisions. IR has a matrix form of organisation at three levels. The levels, in descending order of hierarchy are 
the Railway Board, zones and divisions. While each level is organised on functional departmental lines, functional heads at each level report to both the top manager at that level as well as the functional head at the next level. IR uses two types of project organisations for execution of its projects.

The first type is the zonal project organisation. These zonal project organisations have a strong matrix structure, with the project organisation chief reporting to the zonal head. The project personnel report to the project organisation chief, while taking technical directions and resources from the respective functional organisations of the zone. The project personnel are generally drawn from the respective zones. Since the project team are well versed with the zonal railway network and its operational constraints, and the projects also involve interfacing with the existing running system, they are able to integrate well with the operations organisation for effective project execution.

The second type of project organisation involves reporting directly to the Railway Board. These organisations handle large-scale projects or projects involving work across geographical zones. Examples of such project structures are the Kolkata Metro, the Central Organization for Railway Electrification and the construction organisation for expansion of railway infrastructure in difficult terrains in the north-eastern parts of India. These organisations also have a matrix structure. Their personnel are, however, are drawn from across zones.

In the 1990s, IR started the process of creation of wholly or partially owned public sector corporations (PSCs) for project execution and operation. Typical examples are the Konkan Railway Corporation (KRC), Rail Vikas Nigam Ltd (RVNL) and DFCCIL. The creation of these PSCs was due to a few major reasons:

- The governance of these PSCs is independent of IR. The PSCs' relationship with IR are governed by a negotiated Memorandum of Understanding (MOU) according to guidelines laid down by the Department of Public Enterprises (DPE) (Department of Public Enterprises (Ministry of Heavy Industries and Public Enterprise) 2007) The PSCs have operational autonomy, while being evaluated at periodic intervals on certain previously agreed performance measures by IR.

- The PSCs can frame their own policies regarding human resource recruitment, training, promotion and transfers.

- The PSC personnel are not subject to being transferred out of the PSC before completion of their tenure with the PSC. This enables creation and retention of experienced manpower for project management, and enables the PSC to take up projects in other areas; for example, KRC is executing part of the JUSBRL project.

- The accounts of these PSCs are maintained independent of IR's system. This allows monitoring and control of these organisations, especially in situations where they receive funds from sources other than IR. PSCs have higher autonomy and financial powers in respect to capital expenditure, joint ventures and strategic alliances

- These PSCs have the freedom to modify procurement policies in line with lending agency requirements. 
All the 16 PSCs were manned by IR personnel in the initial stages, with freedom given to the IR personnel to leave the PSC and return to IR. However, since the PSCs lose experienced project personnel as well as knowledge gained during the project, PSCs encourage the personnel to remain in the PSC permanently. DFCCIL has also been recruiting from the open market, in addition to IR personnel presently in the organisation.

DFCCIL was created as a PSC under administrative control of IR, based on the performance of PSCs in project execution and operation. It has been registered under the Companies Act, 1956. The IR chairman is also the chairman of the DFCCIL board of directors. The DFCCIL board comprises the chairman, managing director, four full-time directors - for finance, infrastructure, project planning and operations \& business development; two part-time official directors and two part-time non-official independent directors. During the construction phase, the overall staff strength of DFCCIL would be 930, with 30 staff in each field office. Current staff strength is around 350, of which 140 are on deputation from IR. Officers on deputation from IR are experienced in the project management systems, standards and practices of IR. An MOU is drawn up annually between DFCCIL and IR in accordance with guidelines issued by the DPE. Construction targets and milestones are defined in the MOU. Progress of DFCCIL is appraised in respect to targets set in the MOU. There will also be suitable incentive/penalty scheme based on key performance indices.

Construction of the Eastern DFC is headed by the director project planning (DPP) and that of Western DFC by the director infrastructure located at DFCCIL headquarters, working through its field units. Each field unit is headed by a chief project manager (CPM). DFCCIL has also adopted the matrix structure with personnel reporting to the $\mathrm{CPM}$ and their functional heads at headquarters. The advantages that are accrued from matrix structures are evident from various studies (Larson \& Gobeli 1989; Chuah, Tummala \& Nkasu 1995).

\section{Project financing}

IR projects are generally financed by Budgetary Support and internal resources. However, IR has resorted to financing from external agencies in the case of very large projects. KRC was the first built-operate-transfer (BOT) project constructed with equity participation of IR and the state governments of Karnataka, Kerala, Goa and Maharashtra. This was followed by the joint venture Pipavav Railway Corporation Limited (PRCL) between IR and Gujarat Pipavav Port Limited, with equal equity participation. PRCL has concessionaire rights to construct, operate and maintain the Surendranagar-Rajula-Pipavav Port project line for 33 years. RVNL uses projectspecific equity routes and BOT route for project implementation.

The DFC project requires large resources which obviously cannot be financed only through IR's resources. This project is therefore being funded through a mix of bilateral and multilateral debt, equity and private investment. The debt-equity ratio of the project is 2:1. While the equity component of DFCCIL is being provided by IR, the debt component is being arranged by the Japan International Cooperation Agency (JICA) and the World Bank. The debt component comprises soft loans with long repayment periods of 25 to 40 years and a grace period of 7 to 10 years. Apart from the soft finance, the professional expertise of JICA and World Bank in project management will strengthen DFC project planning and implementation. 
Other recent debt-financed projects of IR include the Rail Sector Improvement Project financed by Asian Development Bank, Delhi-Kanpur Signalling Project financed by Germany and Mumbai Urban Transport Project financed by the World Bank.

According to popular practice, all such loans are received by the Ministry of Finance (MOF) of the Government of India, acting as borrower. MOF passes on the loans to IR as part of Gross Budgetary Support (GBS). IR further passes on these loans to the PSC as equity.

The major features of DFC project funding are as follows:

- JICA loan for construction of Western DFC is estimated at 677 billion Yen. The remaining cost of Western DFC will be borne by IR as equity funding to DFCCIL. The JICA loan is being provided in phases: the first phase for the $930 \mathrm{~km}$ Vadodara-Rewari section; the second phase for the $568 \mathrm{~km}$ JNPTVadodara section. JICA's loan flows to IR through MOF as part of GBS.

- World Bank-IBRD funding is proposed at USD 2.7 billion for construction of the $1188 \mathrm{~km}$ Ludhiana-Mughalsarai section of the Eastern DFC. World Bank loan is structured through Adaptable Programme Loan (APL) scheme for sequential funding of the sections based on a trigger system which takes into account progress of previous sections with regard to land acquisition, civil contract award etc. For this purpose the $1188 \mathrm{~km}$ Ludhiana-Mughalsarai section has been divided into three sections: the first section being funded is the $343 \mathrm{~km}$ Khurja-Kanpur section (APL-1), followed by the KanpurMughalsarai section (APL-2) and Ludhiana-Khurja section (APL-3). The World Bank loan flows directly to IR and then to DFCCIL on a back-to-back basis.

- The $122 \mathrm{~km}$ Mughalsarai-Sonnagar section of Eastern DFC is being funded by IR's internal resources.

- The $524 \mathrm{~km}$ Sonnagar-Dankuni section of Eastern DFC will be funded by a public-private partnership.

IR will pay DFCCIL track access charges for use of DFC tracks by IR's freight trains. Track access charge will have a fixed component covering all the fixed charges including debt repayment, and variable costs will cover operation and maintenance expenses.

\section{Land acquisition process}

Land acquisition for DFC involves over 11,179 hectares spread over 49 districts in seven states. Given the high population density of India, land acquisition for infrastructure projects is quite difficult. Keeping in view the enormity of the task, IR enacted a legislation for land acquisition under the Railways Amendment Act (RAA) in 2008 to provide a better framework for compensation and timeline than the existing Land Acquisition Act 1894.

IR has also adopted the National Resettlement and Rehabilitation Policy 2007 to provide resettlement and rehabilitation (R\&R) assistance to Project Affected Parties (PAPs) on DFC. IR has formulated an Entitlement Matrix for providing land acquisition compensation at replacement cost and adequate $R \& R$ benefits to the relevant categories of the affected families, in consultation with JICA and World Bank. The Entitlement Matrix has also incorporated the feedback received project- 
wide Public Consultation Meetings held with the PAPs by CPMs of DFCCIL. The land acquisition process is being carried out with the support from Land Acquisition Consultants, who undertake land surveys and coordinate with the local revenue departments. DFCCIL is also hiring non-government organisations to assist in community participation, livelihood and skill improvement activities and to support affected persons in articulating their grievances.

IR/DFCCIL has developed a well-defined institutional procedure for handling grievances and complaints relating to land acquisition. The authority appointed for carrying out land acquisition as per the RAA will be the first level for hearing and resolving objections relating to the land acquisition process. Independent arbitrators will hear and redress grievances relating to compensation awards according to the RAA. A two-stage grievance redress mechanism has been set out at the field and corporate levels. IR has also appointed an Ombudsman to deal with unresolved grievances related to $R \& R$ assistance. IR would also engage a Social and Environment Safeguards Monitoring and Review Consultant for third party monitoring and annual quality audit of the implementation of land acquisition and R\&R measures (World Bank 2011).

DFCCIL has also established a Social and Environment Management Unit (SEMU) for overseeing management of environmental and social safeguard measures. The SEMU includes experienced environmental management and social development specialists. At the field level, the CPM coordinates the safeguard management activities.

The above steps have resulted in successful acquisition of over two-thirds of the land requirement so far. This is a significant achievement in project preparation, considering that the civil contracts of both World Bank and JICA-funded portions are still to be awarded. Acquisition of over $80 \%$ land is targeted before award of the contracts.

\section{Project procurement process}

IR construction procurement is based on traditional item-rate contracts where the responsibility of design is with the employer. Studies reveal that such contracts are prone to time delays and cost overruns.

A cardinal principle for successful project execution is comprehensive risk mapping, with risks being allocated in such a manner that the party most appropriate to assess probability of occurrence of a particular risk and capable of initiating suitable mitigation measures bears that particular risk. A modified contract type, Design-Build Lump Sum (DBLS) contracting strategy has been adopted for DFC projects in line with this principle. Here, the project owner carries out preliminary site surveys and concept design whereas the contractor performs detailed engineering design and surveys, appropriate to the contract time and cost. This type of contracting strategy is most appropriate in situations with low uncertainty of product and high uncertainty of the process of delivery (Turner \& Simister 2001). DBLS-type contracts effectively transfer the design risk from the owner to the contractor. The contract has an in-built incentive component for the contractor to ensure the accuracy of surveys and the quality of design (World Bank 2011). 
Further, DFCCIL has adopted the FIDIC Yellow Book (Federation Internationale des Ingenieurs-Conseils (FIDIC) 1999), with certain modifications listed below, for all its contracts, instead of IR's General Conditions of Contract (Engineering Department, Indian Railways 2010) to transfer some risks from employer to contractor to achieve higher certainty of cost and time:

i. Clause 1.9 - Errors in Employer's requirements

ii. Clause 4.7 - Errors in setting out

iii. Clause 4.10 - interpretation of site data

iv. Clause 4.12 - unforeseeable physical conditions

v. Clause 8.3-Programme - Deletion of variation on account of future events or circumstances

vi. Clause 8.4-Extension of time for completion on account of adverse climatic conditions

The implications of adoption of FIDIC Yellow Book vis-à-vis IR General Conditions of Contract is given in Table 5.

Table 5: FIDIC Yellow Book vis-à-vis IR General Conditions of Contract

\begin{tabular}{|c|c|c|}
\hline No. & Railway general contract conditions & FIDIC Yellow Book conditions \\
\hline 1 & Design responsibility with Employer & $\begin{array}{l}\text { 1. Only indicative design given by } \\
\text { Employer to Contractor. Contractor is } \\
\text { responsible for developing all design - } \\
\text { Preliminary Design, Definitive Design } \\
\text { and "Good for Construction } \\
\text { Drawings". }\end{array}$ \\
\hline 2 & $\begin{array}{l}\text { Work is done and measured in terms of quantities } \\
\text { for separate items. Payment as per Bill of } \\
\text { Quantities. The quantity estimation risk is with the } \\
\text { employer. }\end{array}$ & $\begin{array}{l}\text { 2. Works is done and payment made on } \\
\text { Design Build Lumpsum basis. Quantity } \\
\text { estimation risk transferred to Contractor } \\
\text { substantially. }\end{array}$ \\
\hline 3 & Contract Administration by Employer & $\begin{array}{l}\text { 3. Contract Administration by } \\
\text { ENGINEER on behalf of Employer }\end{array}$ \\
\hline 4 & Low price certainty & 4. High price certainty \\
\hline
\end{tabular}

Further, DFCCIL is being supported by the following experts in its procurement activities:

- A "General Consultant(GC)/Engineering Services Consultant (EC)" appointed for each section of DFC to prepare the scope and the engineering plans before bidding and for rendering technical advice in the design of the project

- A "Project Management Consultant (PMC)" being appointed for supervision of construction work relating to contract management, construction supervision, monitoring time schedule, checking and approval of designs and drawings, quality checking, ensuring work site safety preparation of operation $\&$ maintenance manuals for various components of works. The PMC will also perform the function of "Engineer" as required under FIDIC contracts.

- A "Design Review Consultant" appointed to review preliminary designs against international good practices, as well as to conduct value engineering.

- A "Civil Engineering Proof Consultant" appointed to verify the accuracy of surveys, quantities, material sources and cost estimates for civil and track works on a sample basis. 
- A "Legal Advisor" appointed is to provide advisory on the preparation of bid documents, assistance during the bidding process and also to coordinate contract management activities once the main contracts have been awarded.

- A "Quality and Safety Audit Consultant" to be appointed to assist DFCCIL to monitor construction quality, and the implementation of safety plans during project implementation.

\section{Discussion}

A large number of stakeholders are involved in the DFC project implementation. They include the IR, zonal railways, Planning Commission, MOF, Ministry of External Affairs, DFCCIL, lending agencies (JICA and World Bank), nine state governments (Punjab, Haryana, Uttar Pradesh, Bihar, West Bengal, Rajasthan, Gujarat, Maharashtra, Delhi), land owners and project affected parties, contractors, material suppliers and consultants. The relationship between these stakeholders is depicted in Figure 2. Effective coordination among these stakeholders is being facilitated by a cell in Ministry of Railways to expeditiously resolve financial, environmental, social, land compensation, resettlement, engineering, contractual, legal and organisational issues that are critical for successful completion of the project.

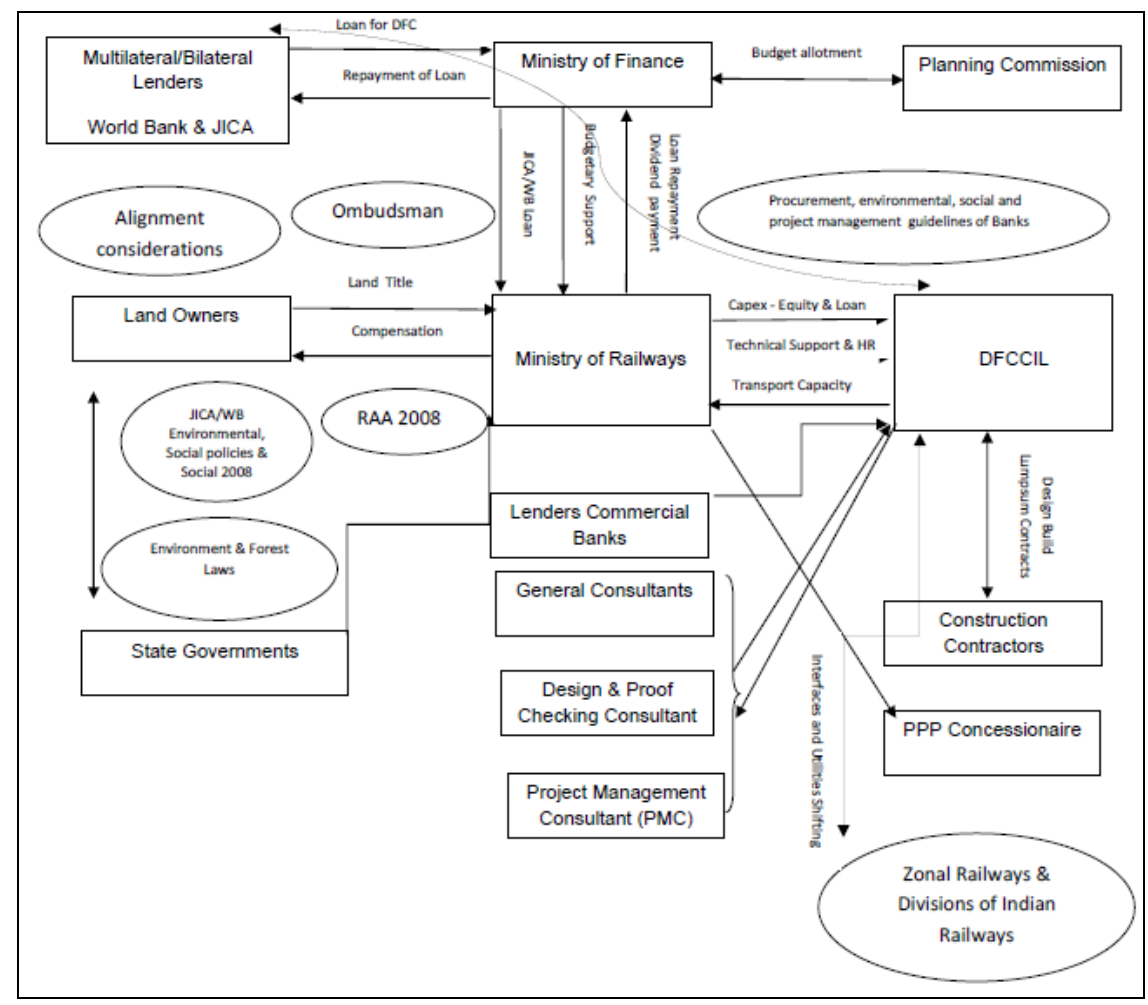

Figure 2: DFC stakeholder relationships.

It may be recalled that the major reason for time and cost overruns of IR projects has been the inadequacy of funds being allotted for projects. Tying up loans to the extent of about $70 \%$ of the project cost with JICA and the World Bank addresses the issue of inadequacy of funds for the DFC project. We examine the other major reasons of time and cost overruns (Ministry of Statistics and Programme Implementation (Infrastructure \& Project Monitoring Division), Government of India 2008) and the 
role of these stakeholders, the project structure, the project land acquisition processes, financing and contractual process in mitigating overruns in Table 6.

Table 6: Common reasons for time and cost overruns and their mitigation measures

\begin{tabular}{|c|c|c|}
\hline No. & Reasons for Time/Cost Overruns & Mitigation Measures \\
\hline (i) & $\begin{array}{l}\text { Lack of supporting infrastructure } \\
\text { facilities }\end{array}$ & $\begin{array}{l}\text { All the supporting infrastructure has been built into } \\
\text { contractor's scope of work. This supporting } \\
\text { infrastructure includes service roads, all temporary } \\
\text { works required to facilitate construction, site office, } \\
\text { communication, inspection and transport facilities, } \\
\text { provision of power and water etc }\end{array}$ \\
\hline (ii) & $\begin{array}{l}\text { Delay in finalisation of detailed } \\
\text { engineering plans and release of } \\
\text { drawings }\end{array}$ & $\begin{array}{l}\text { General Consultants/Engineering Services } \\
\text { Consultants have been engaged for each section of } \\
\text { DFC to prepare the scope and the conceptual } \\
\text { engineering plans before bidding. } \\
\text { Geotechnical, hydrological, seismic and } \\
\text { environmental surveys carried out before } \\
\text { commencement of bidding } \\
\text { Elaborate design procedures, criteria, } \\
\text { specifications and processes with clear } \\
\text { responsibilities outlined in bid document. } \\
\text { Project Management Consultant appointed for } \\
\text { supervision of construction work } \\
\text { Interfaces and obligations of contractors to other } \\
\text { contractors defined in bid document } \\
\text { Preparatory works such as environmental impact } \\
\text { assessment, social impact assessment, public } \\
\text { consultations, resettlement and rehabilitation } \\
\text { undertaken before biding } \\
80 \% \text { of land acquisition is required to be } \\
\text { completed before award of contract }\end{array}$ \\
\hline (iii) & $\begin{array}{l}\text { Changes in scope or delay in finalisation } \\
\text { of the scope }\end{array}$ & \\
\hline (iv) & $\begin{array}{l}\text { Industrial relations and law and order } \\
\text { problems }\end{array}$ & $\begin{array}{l}\text { Safety, Health and Environment manual drawn up } \\
\text { by owner, incorporating best practices laid down } \\
\text { in relevant legal provisions and appropriate for } \\
\text { execution of projects with such complexity, to } \\
\text { guide contractors' efforts towards maintaining } \\
\text { industrial relations and law and order. Suitable } \\
\text { rewards and penalties in this regard defined in bid } \\
\text { document. } \\
\text { social impact assessment carried out in advance, } \\
\text { which enables deployment of counter-measures in } \\
\text { advance } \\
\text { process of stakeholder consultation incorporated } \\
\text { in project planning and execution process } \\
\text { regular coordination is maintained with state } \\
\text { governments on security issues }\end{array}$ \\
\hline (v) & lack of familiarity with latest technology & $\begin{array}{l}\text { General Consultants engaged to prepare } \\
\text { specification, design and bid documents in line } \\
\text { with international best practices } \\
\text { Comprehensive evaluation of bidders' Technical } \\
\text { Proposals to assess their familiarity with } \\
\text { technology appropriate for the work } \\
\text { Interfaces defined } \\
\text { PMC will be reviewing construction methodology } \\
\text { at critical stages to ensure that project construction } \\
\text { methodology employs technologies appropriate } \\
\text { within the time and budget constraints }\end{array}$ \\
\hline
\end{tabular}




\begin{tabular}{|c|c|c|}
\hline (vi) & Unanticipated geological conditions & $\begin{array}{l}\text { DFCCIL has undertaken preliminary geotechnical, } \\
\text { hydrological, seismic, environmental surreys and } \\
\text { included these in the bid documents wherever } \\
\text { appropriate, with instructions to bidders to satisfy } \\
\text { themselves with the accuracy of surveys provided and } \\
\text { to undertake their own surveys before submitting their } \\
\text { bids and to carry out detailed surveys and remedial } \\
\text { works, if any, during contract execution. }\end{array}$ \\
\hline (vii) & $\begin{array}{l}\text { Changes in rates of foreign exchange } \\
\text { and statutory duties }\end{array}$ & $\begin{array}{l}\text { Foreign currency denominated loan, close coordination } \\
\text { maintained with Ministry of Finance regarding } \\
\text { statutory duties }\end{array}$ \\
\hline (viii) & $\begin{array}{l}\text { increase in cost of rehabilitation of } \\
\text { displaced persons and providing } \\
\text { environmental safeguards }\end{array}$ & $\begin{array}{l}\text { Environment \& Social Impact Analysis completed in } \\
\text { advance; hence cost included in project cost estimate. }\end{array}$ \\
\hline (ix) & increase in cost of land acquisition & $\begin{array}{l}\text { Land acquisition cost is now statutorily defined and } \\
\text { built in the project cost estimate }\end{array}$ \\
\hline$(\mathrm{x})$ & inflation over project duration & $\begin{array}{l}\text { Inflation based on WPI is built in the project cost } \\
\text { estimate }\end{array}$ \\
\hline (xi) & $\begin{array}{l}\text { lack of commitment by client, contractor } \\
\text { and vendors leading to accidents, } \\
\text { improper or obsolete construction } \\
\text { methods, delay in material delivery }\end{array}$ & $\begin{array}{l}\text { As discussed in (iv) above, DFCCIL has developed a } \\
\text { Safety, Health and Environment manual incorporating } \\
\text { best practices to prevent accidents. Comprehensive } \\
\text { review of Technical Proposals submitted by bidders } \\
\text { and periodic review of construction methodology and } \\
\text { rolling program by PMC will mitigate risks emanating } \\
\text { from adoption of improper or obsolete construction } \\
\text { methods and/or delay in material delivery. }\end{array}$ \\
\hline (xii) & $\begin{array}{l}\text { inefficient site management due to } \\
\text { ambiguous specifications, unskilled } \\
\text { labour, ineffective supervision, } \\
\text { inadequate experience of contractor, } \\
\text { lack of control over sub-contractors }\end{array}$ & $\begin{array}{l}\text { Measures such as appointment of General } \\
\text { Consultant/Engineering Services Consultant for } \\
\text { drafting of bid specifications, DBLS contracting } \\
\text { strategy, bid conditions requiring bidders to submit } \\
\text { their understanding of bid specifications, experience } \\
\text { and technical profile of proposed organisation, } \\
\text { construction methodology and work program as part of } \\
\text { their Technical Proposals and review of bidders' } \\
\text { Technical Proposals, appointment of PMCs and Design } \\
\text { Review Consultants are aimed at mitigating these risks. }\end{array}$ \\
\hline (xiii) & $\begin{array}{l}\text { poor site coordination due to lack of } \\
\text { coordination between site and design } \\
\text { office, non-availability of } \\
\text { drawings/designs on time, unrealistic } \\
\text { time schedule built in the contract }\end{array}$ & $\begin{array}{l}\text { Suitable provisions such as periodic submission and } \\
\text { review of drawings/designs by the contractor prior to } \\
\text { commencement of relevant portion of work, adoption } \\
\text { of consistent drawing software across all contracts etc. } \\
\text { aim at reducing these risks. Extensive due diligence by } \\
\text { DFCC, IR and lending agencies (JICA and World } \\
\text { Bank) has been carried out to avoid the error of } \\
\text { committing to unrealistic time schedules. }\end{array}$ \\
\hline (xiv) & $\begin{array}{l}\text { improper planning in ignoring extreme } \\
\text { weather conditions which lead to low } \\
\text { labour productivity and therefore lead to } \\
\text { errors in time estimation; in planning for } \\
\text { recruitment of skilled operators for } \\
\text { specialised equipment; in planning the } \\
\text { requirement of equipment and their } \\
\text { utilisation }\end{array}$ & $\begin{array}{l}\text { Measures such as indicating site climatic conditions in } \\
\text { the bid documents and preparation of Safety, Health } \\
\text { and Environment with appropriate penalty/incentive } \\
\text { mechanism aim at mitigating risks emanating from low } \\
\text { labour productivity due to extreme weather conditions. } \\
\text { To address the issue of errors in estimation of } \\
\text { requirement/deployment of specialised equipment and } \\
\text { skilled operators for such specialised equipment, bid } \\
\text { conditions require bidders to include their deployment } \\
\text { program for construction machinery and specialised } \\
\text { equipment and required construction organisation as } \\
\text { part of their Technical Proposals. Comprehensive } \\
\text { review of bidders' Technical Proposals and } \\
\text { appointment of PMCs are likely to help mitigate risks } \\
\text { arising from errors in estimation of } \\
\text { requirement/deployment of specialised equipment and } \\
\text { skilled operators for such specialised equipment. }\end{array}$ \\
\hline
\end{tabular}




\begin{tabular}{|l|l|l|}
\hline (xv) & $\begin{array}{l}\text { lack of clarity of project scope resulting } \\
\text { in rework or scope creep due to } \\
\text { misunderstanding by the contractor or } \\
\text { project manager }\end{array}$ & $\begin{array}{l}\text { Appointment of General Consultants/Engineering } \\
\text { Consultants, preliminary geotechnical, hydrological, } \\
\text { seismic and environmental surveys provided, bid } \\
\text { conditions requiring bidders to carry out their own } \\
\text { surveys, bid conditions requiring submission of } \\
\text { bidders' Technical Proposals incorporating their } \\
\text { understanding of bid specifications and comprehensive } \\
\text { review thereof and appointment of Design Review } \\
\text { Consultants appear to be effective countermeasures. }\end{array}$ \\
\hline (xvi) & $\begin{array}{l}\text { lack of communication with local } \\
\text { authorities resulting in delays in } \\
\text { permissions; lack of communication } \\
\text { between contractor and client results in appointed Chief Project Managers at } \\
\text { delay in approval of stages } \\
\text { appropriate locations all though the proposed corridors } \\
\text { to help coordinate communication between contractors } \\
\text { and local authorities to avoid any delay on such } \\
\text { account. }\end{array}$ \\
\hline $\begin{array}{l}\text { substandard contract, selection of } \\
\text { contractor with inadequate experience } \\
\text { skill sets, optimistic cost and time } \\
\text { duration built in the contract }\end{array}$ & $\begin{array}{l}\text { Contract conditions require that the contractor shall } \\
\text { seek prior consent of the Engineer before deployment } \\
\text { of any subcontractor. Contract conditions also specify } \\
\text { that the main contractor shall be responsible for acts or } \\
\text { defaults of any subcontractor. As discussed above, } \\
\text { adequate safeguards have been envisaged at the } \\
\text { planning, bidding and execution stages to reduce } \\
\text { possibility of committing to optimistic cost and time } \\
\text { duration. }\end{array}$ \\
\hline xvii) &
\end{tabular}

\section{Future research directions}

The magnitude of the DFC project and the number of national and international stakeholders involved makes it an ideal candidate for research in a number of areas. A few areas that are immediately evident are the evaluation of the mitigation measures over the project duration; efficacy of FIDIC contractual methods in Indian public sector contracts; study of contract performance of DFC vis-à-vis IR; contractor perceptions of efficacy of design-build contracting; supporting consultants' evaluation and selection methodology; efficacy of supporting consultants; and effects of contract incentives and disincentives.

\section{References}

Chuah, KB, Tummala, VMR \& Nkasu, MM 1995, Project management structures in Hong Kong industries, International Journal of Project Management, vol. 13, no. 4, 253-257.

Dedicated Freight Corridor Corporation of India Ltd 2012, DFCCIL, viewed 26 September 2012, http://dfccil.org/DFCC/Home/Home.

Department of Public Enterprises (Ministry of Heavy Industries and Public Enterprise) 2007, Guidelines for MOU for the Year 2006-07, viewed 27 September 2012 http://dpe.nic.in/e documents/archives/Guidelines/newsite/MoU0607.

Doloi, H, Sawhney, A, Iyer, KC \& Rentala, S 2012, Analysing factors affecting delays in Indian construction projects, International Journal of Project Management, vol. 30, 479-489.

Engineering Department, Indian Railways 2010, Regulation of Tender and Contracts \& General Conditions of Contract, viewed 25 September 2012, http://www.indianrailways.gov.in/railwayboard/uploads/directorate/civil engg/pdf/GCC.pdf.

Federation Internationale des Ingenieurs-Conseils (FIDIC) 1999, Plant and Design-Build for Electrical and Mechanical Plant, and for Building and Engineering Works, Designed by Contractor, FIDIC, Geneva.

Indian Railways 2012, Indian Railways Year Book 2010-11, Ministry of Railways, Government of India, Ministry of Railways, New Delhi.

Larson, EW \& Gobeli, DH 1989, Significance of project management structure on development success, IEEE Transactions on Engineering Management, vol 36, no. 2, pp. 119-125.

McKinsey and Company 2010, Building India:Transforming the Nation's Logistics Infrastructure, viewed 25 September 2012,

http://www.mckinsey.com/locations/india/mckinseyonindia/pdf/Logistics_Infrastructure_by20 20 fullreport.pdf.

Ministry of Railways (Railway Board) 2009, Indian Railways Vision 2020, Railway Board, New Delhi. 
Ministry of Railways, Government of India 1952, Annual Statistical Statement 1950-51, Efficiency \& Statistics, Railway Board, Ministry of Railways, New Delhi.

Ministry of Railways, Government of India 2009, White Paper on Indian Railways, viewed 26 September 2012,

http://www.indianrailways.gov.in/railwayboard/uploads/directorate/planning/downloads/Whit e\%20Paper_Eng_SUBMITTED\%20To\%20Parliament.pdf.

Ministry of Statistics and Programme Implementation (Infrastructure \& Project Monitoring Division), Government of India 2008, Project Implementation Status Report of Central Sector Projects costing Rs.20 crore and above (April-June 2008), viewed 25 September 2012, http://www.mospi.gov.in.

Planning Commission 2012, Select Economic \& Social Indicators-India (1950-51 to 2010-11), viewed 26 September 2012, http://planningcommission.nic.in/data/datatable/0904/tab 6.pdf.

RITES Ltd 2008, Total Transport System Study on Traffic Flows \& Modal Costs (Highways, Railways, Airways \& Coastal Shipping), viewed 25 September 2012, http://planningcommission.nic.in/reports/genrep/index.php?repts=rites.html.

Saxena, RN 1991, Four Decades of Indian Railways (1950-1990), 1st ed., Academic Foundation, Delhi.

Secretariat for the Committee on Infrastructure, Planning Commission 2005, Report of the Task ForceThe Delhi-Mumbai and Delhi-Howrah Freight Corridors, viewed 26 September 2012, www.infrastructure.gov.in.

Turner, JR \& Simister, SJ 2001, Project contract management and a theory of organisation, International Journal of Project Management, vol 19, 457-464.

World Bank 2011, India - Eastern Dedicated Freight Corridor Project Appraisal Document, viewed 25 August 2012, http://documents.worldbank.org/curated/en/2011/05/14176907/india-easterndedicated-freight-corridor-project.

World Bank 2012, Logistics Performance Index: Connecting to Compete 2012, viewed 26 September 2012 ,

http://web.worldbank.org/WBSITE/EXTERNAL/TOPICS/TRADE/0,contentMDK:23188613 $\sim$ pagePK:210058 piPK:210062 theSitePK:239071,00.html.

\footnotetext{
About the authors

Bodhibrata Nag is an Associate Professor in the Operations Management Group of the Indian Institute of Management Calcutta. He received his PhD (Fellow) in Operations Research and System Analysis from the Indian Institute of Management Calcutta and his Bachelor of Technology degree in Electrical Engineering from the Indian Institute of Technology Madras. He is trained in the case method of teaching and case development at the Harvard Business School and power projects design at Electricite de France. He has more than twenty years of industry experience in senior management positions in the Indian Railways and the Central Electricity Authority. He has co-authored two books, Optimal Design of Timetables for Large Railways and Introduction to Operations Research. He is a Fellow of the Institution of Engineers (India) and a Senior Member of the Institution of Electrical and Electronics Engineers. He was a visiting faculty at the University of Michigan and was awarded the FulbrightNehru Senior Research Fellowship. His research interests are application of analytic techniques for planning, design and operations of energy and logistics systems.

Jeetendra Singh has a B.E. (Electrical Engineering) from VNIT, Nagpur, and PGPEX MBA from IIM Kolkata. He is the Director Planning (Special) in Infrastructure Directorate of Railway Board, Ministry of Railways. His present assignment includes formulation and implementation of Five Year plans for the railway sector, planning, financing and implementation of the Heavy Haul Eastern and Western Dedicated Freight Corridor project, planning for raising speeds of passenger trains on existing New Delhi-Mumbai route to $160 / 200 \mathrm{kmph}$ and technology-specific international cooperation initiatives of Indian Railways with advanced railways of the World. Tying up JICA and World Bank funding for the DFCs is his major focus area. He is from the Indian Railway Service of Electrical Engineers and has significant field-level experience in Construction, Operation \& Maintenance of Traction \& General Power Supply Infrastructure and Electric Rolling Stocks.
} 
Ved Mani Tiwari has a B.E. (Electrical Engineering) from MMMEC, Gorakhpur, and is currently pursuing a PGPMAX MBA from ISB Hyderabad. He is currently the Director (Development) in Electrical Engineering Directorate of Railway Board, Ministry of Railways. His present assignment includes developing strategies and frameworks for private sector participation in railway sector under public private partnership, implementation of projects under CDM mechanism under UNFCCC

framework for generating alternative revenues for Indian Railways, development of new technologies for Indian Railways and procurement of locomotives for Dedicated Freight Corridors. He is from the Indian Railway Service of Electrical Engineers and has significant field-level experience in

Construction, Operation \& Maintenance of Traction \& General Power Supply Infrastructure and Electric Rolling Stocks in Indian Railways and DMRC. 